\title{
Bioinvasion of Tradescantia zebrina Heynh. (Commelinaceae) in uplands, State of Paraíba, Brazil
}

\section{Danielle Brígida Candeia Ribeiro ${ }^{1}$, Juliano Ricardo Fabricante $^{2}$ and Manoel Bandeira de Albuquerque ${ }^{1}$}

${ }^{1}$ Universidade Federal da Paraíba (UFPB), Campus de Ciências Agrárias (CCA), CEP 58397-000, Areia, PB, Brazil.

${ }^{2}$ Universidade Federal do Vale do São Francisco (UNIVASF), Centro de Referência para Recuperação de Áreas Degradadas (CRAD), BR 407, km 12, lote 543, Projeto de Irrigação Nilo Coelho - S/N C1, CEP 56300-000, Petrolina, PE, Brazil. E-mail: julianofabricante@hotmail.com.

\begin{abstract}
The study of invader species and their consequences to the environment represents an important reinforcement to the knowledge of environmental preservation. This work aimed to evaluate the invasive aspects of Tradescantia zebrina Heynh., subsidizing information to their adequate management or control. The study area is compound by a Open Ombrophylous Forest in the Municipality of Areia, Paraíba State, Brazil. The evaluated variables were populational density, biomass, biometry, invasion velocity and impacts of species under resilience of native vegetation. The results found density of $627 \pm 16$ individuals $/ \mathrm{m}^{2}, \quad$ (mean \pm standard deviation), $25.9 \pm 68 \mathrm{~cm}$ length and $0.21 \pm 0.03 \mathrm{~cm}$ de diameter with positive relationship between both variables $(r=0.24 ; t=2.4$; $\mathrm{p}=0.02$ ) and biomass of $16.9 \mathrm{~g}$ (leaves), $10.6 \mathrm{~g}$ (stems) and $1.3 \mathrm{~g}$ (roots) for each 100 sampled individuals, being that in each $\mathrm{m}^{2}$, reached to have $18.8 \pm 5,1 \mathrm{~g}$ leaf biomass, $22.4 \pm 7.6 \mathrm{~g}$ stem biomass and $3.4 \pm 1.3 \mathrm{~g}$ root biomass. The population showed a rapid expansion occupying $0.30 \pm 0.09 \mathrm{~m}^{2}$ after seven days and $0.51 \pm 0.15 \mathrm{~m}^{2}$ in eighty four days. Parcels without the invader species (SE) showed expansive accumulation of individuals throughout the evaluation time, while in the parcels with the species (CE) the number of individuals exhibit few changes $(p=0.021$ and $\mathrm{H}=5.327$ ). The results exhibit the biological invasion in the UFPB Campus II by T. zebrina, represents a threat to the local biodiversity due to its aggressive invasive behavior.
\end{abstract}

Keywords: Biological contamination, upland forest, competition.

\section{Introduction}

Biological invasion is the process of introduction of a species outside its natural range, where they become established and able to disperse and may produce negative impacts on the ecosystem and native species. These introductions of exotic species, intentionally or not, are frequently associated to human activities. Since the earliest human movements by land and/or ocean the transportation of plant and animals, which are used as food source throughout the journey or to help the human establishment in the final destination, have resulted in introduction of organisms in places where it can become pests (Lockwood et al., 2001; Mack et al., 2000). Although it has been a problem identified long time ago - Darwin mentioned this 
phenomenon in his On the Origin of Species by Means of Natural Selection (Ludsin and Wolfe 2009) - in the last decades, exotic species introduction has received more attention, not only by researchers and students, but also by the politicians and governments, due to the biodiversity and economic losses. Pimentel et al. (2001) affirms that biological invasions has impact on diverse sectors such as agriculture, forestry, aquaculture, transportation, trade, power generation and recreation with estimated losses around 5\% of the global economy (more than US \$ 1.4 trillion annually). Thus, the study of invader species and its consequences to the environment have increased in importance and acceptance among researchers, and represent an important reinforcement to the environmental preservation studies (Casimiro et al., 2010).

Besides the knowledge that some plant species possess intrinsic features that can allow them to become an invader (such as: high rates of reproduction and dispersion, phenotypic plasticity, short generations and long lifetime), some features can turn a given community particularly more susceptible to the invasion than others. Among these features, we detached: possess similar climate to the habitat of invader, be in the early succession stages, absence of predators (herbivores), absence of native species with morphological or ecological similarities and modified by anthropic action (Meffe and Carroll, 1997). When the man dominates geographical areas suitable to its needs, often it does not consider the environmental component present there (water resources, topography, fauna and flora) and develop agriculture, recreation, housing, roads and other facilities aimed at the economic activity that can generate disturbance and local extinction of the remaining nature (Biondi and Pedrosa-Macedo 2008).

In the northeastern region the landscape is predominated by a savanna stepic-like dry forest (locally known as Caatinga), that covers $734.478 \mathrm{~km}^{2}$, almost $70 \%$ of Brazilian northeastern (Silva et al., 2003, Santos and Melo, 2010). However, in this region is possible to find kind of rainforest disjunction formed by islanded mountain woods locally known as "Brejo de Altitude", a kind of uplands whose remaining areas possess high biodiversity (Barbosa et al., 2004). Despite its environmental and socio-economic importance, the Atlantic Rainforest in Brazilian northeastern has suffered for decades with the degradation, especially for the implantation of the monoculture of sugarcane that resulted in the rising of a fragmented Atlantic landscape (Silva et al., 2006).

In some regions of the world, Tradescantia zebrina Heynh. is been pointed out as invader seen that it can interfer in the development of others plant species T. zebrina is a monocot native from Mexico and Central America (Lorenzi and Souza 2001), introduced in Brazil with landscape purposes (Rodolfo et al., 2008). Characterized as purplish-green and glabrous, prostrate herb which is rooted by nodes, having a preference for places with full or semi-shade and fertile soil, rich in organic matter and slightly humid (Instituto Hórus de Desenvolvimento e Conservação Ambiental, 2005).

T. zebrina is responsable by the invasions of Steppes, Quasi and Dense Ombrophylous Forests (Instituto Hórus de Desenvolvimento e Conservação Ambiental, 2005). This is the first register of T. zebrina invasion in the Campus II of Universidade Federal da Paraíba, where the typical vegetation is Open Ombrophylous Forest.

The present work aimed to evaluate the invasive aspects of the species T. zebrina in an Open Ombrophylous Forest fragment, to produce information that subside a future planning for adequate either control or management of this species.

\section{Materials and Methods}

\section{Study area}

The study area is an Open Ombrophylous Forest fragment located in the Areia Municipality, Paraíba State $\left(6^{\circ} 58^{\prime} 12^{\prime} \mathrm{S}, 35^{\circ} 42^{\prime} 15^{\prime} \mathrm{W}\right.$ and $580 \mathrm{~m}$ mean altitude). Its rainfall is around 1400 $1600 \mathrm{~mm}$, annual mean temperature $22^{\circ} \mathrm{C}$ and relative moisture around $85 \%$. Soils are deep and moderately fertile, classified as 
dystrophic yellow oxisol and relief quite rugged (Mayo and Fevereiro, 1982).

\section{Populational Density}

The density was estimated through the parcel method (Müller-Dombois and Ellemberg, 1974), with a total of ten samples $(1 \mathrm{mx} 1 \mathrm{~m}$ each). They were randomly plotted in the study area. In each one was counted the numbers of individuals, been considered each stem apex as one specimen. The density was calculated by the statistical software Bioestat 5.0 (Ayres et al., 2007).

\section{Biomass and biometry}

The biomass measures were made by two ways: (I) By parcel - in the sample unities used to estimate the species density all individuals were collected and separated in parts (roots, stem and leaves), oven dried $\left(65^{\circ} \mathrm{C}\right)$ and weighted. By the sum of the parts it were obtained the total dry biomass and by parcel; (II) By individual Randomly were collected one hundred individuals whose their morphological structures were separated (roots, stems and leaves), oven dried $\left(65^{\circ} \mathrm{C}\right)$ and weighted. The biometry was obtained from these one hundred specimens by the measurements of length and stem diameter. These values were still correlated by Pearson ( $\rho$ ) (Rodgers and Nicewander, 1988), being verified by $t$ test $(p \leq 0,05)$ (Lehmann, 1997), with the use of statistical software Bioestat 5.0 (Ayres et al., 2007).

\section{Invasion velocity of $T$. zebrina}

Ten parcels $(1 \mathrm{mx} 1 \mathrm{~m})$ were placed in the area and all inner individuals were removed. To evaluate the time necessary to filling again the parcel, aerial photos were taken at $7,21,35,56,70$ and 84 days after the removal. By the use of the software SisCob 1.0 (Embrapa) the plant cover was quantified (Jorge and Silva, 2003). The data were used to obtain linear regression.

\section{Impacts of $T$. zebrina about the resilience of native vegetation}

In five parcels $(1 \mathrm{~m} \mathrm{x} 1 \mathrm{~m})$ the plant species was removed and monthly during 10 months were counted all seedlings of native plant species. Other five parcels without removal were observed as control treatment.

The comparison between treatments was performed by a ANOVA (KruskalWallis - H) and the significance between averages by Dunn's test $(p \leq 0,05)$, with the use of the statistical software Bioestat 5.0 (Ayres et al., 2007).

\section{Results}

\section{Populational density, biomass and biometry of $T$. zebrina}

The mean density of $T$. zebrina reached high value $\left(627 \pm 16\right.$ individuals $\left./ \mathrm{m}^{2}\right)$ that can characterize a dense population representing a strong threat to the native species. The biometric measurements of one hundred individuals showed a positive correlation between length and diameter $(\mathrm{r}=0.24 ; \mathrm{t}=2.4 ; \mathrm{p}=0.0172)$. For length the mean value was $25.9 \pm 68 \mathrm{~cm}$ (lower $11.7 \mathrm{~cm}$ and upper $42.9 \mathrm{~cm}$ ), while for diameter the mean value was $0.21 \pm 0.03$ (lower 0.2 and upper $0.3 \mathrm{~cm}$ ) (Figure 1).

Biomass values were significantly different for the 100 adult individuals and individuals selected sampling. For 100 adults, the leaves had a higher biomass $(16.9 \mathrm{~g})$ of the stems $(10.6 \mathrm{~g})$. However, for individuals of sampling $\left(10 \mathrm{~m}^{2}\right)$, it was found that the sheets obtained values of dry biomass per $\mathrm{m}^{2}$ of from $7.5 \mathrm{~g}$ to $2.23 \mathrm{~g}$ with an average lower $(18.8 \pm 5.1 \mathrm{~g})$ to the found stems $(22.4 \pm 7.6 \mathrm{~g})$ showed that minimum and maximum values of $9.7 \mathrm{~g}$ and $37.3 \mathrm{~g}$, respectively. This probably happened because individuals of the sample $\left(10 \mathrm{~m}^{2}\right)$ were taken randomly and without age criteria, involving those with tillers.

The dry root biomass showed the lower values among the others plant structures $3.4 \pm 1.3 \mathrm{~g}$ per $\mathrm{m}^{2}$ and $1.3 \mathrm{~g}$ per 100 individuals, as expected for stoloniferous herbs. 


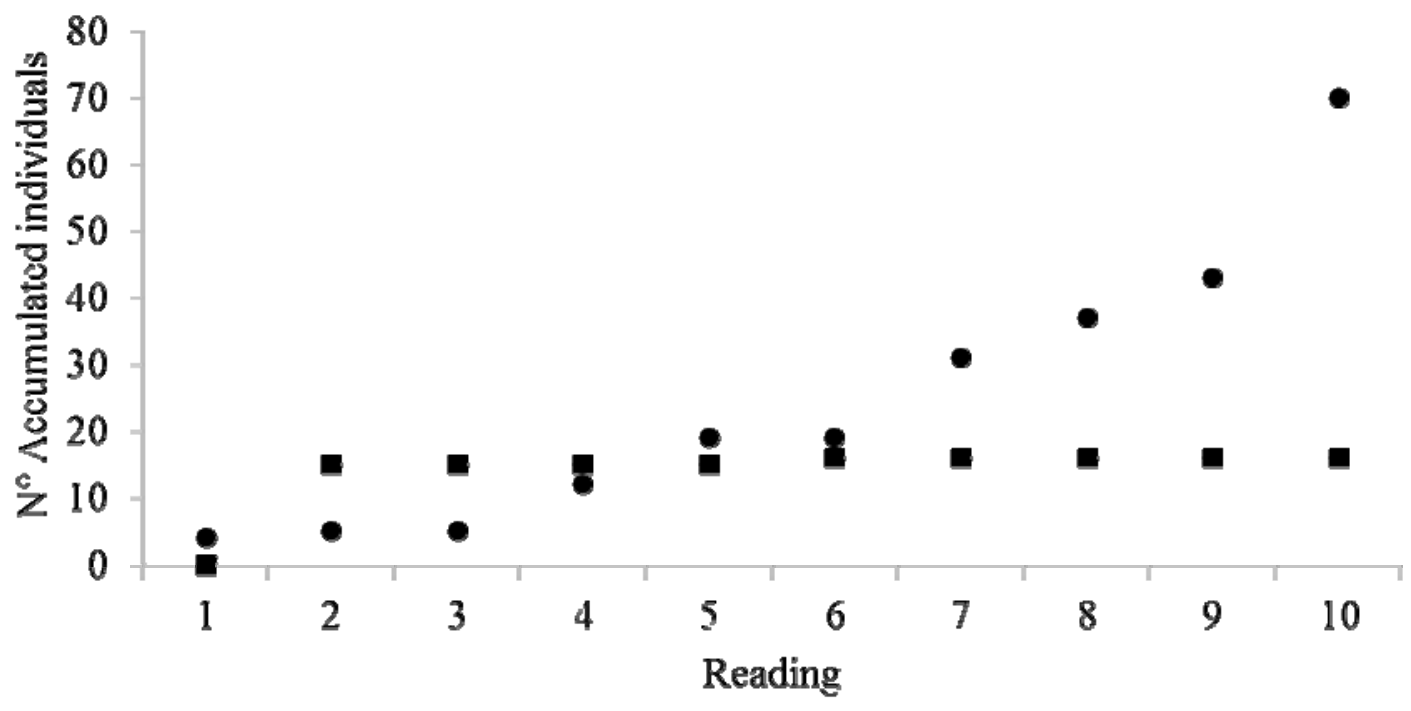

- Sem a espécie - Com a espécie

Figure 1. Cumulative number of individuals in plots without the species and with the species in function of monthly readings on Campus II UFPB, Areia-PB.

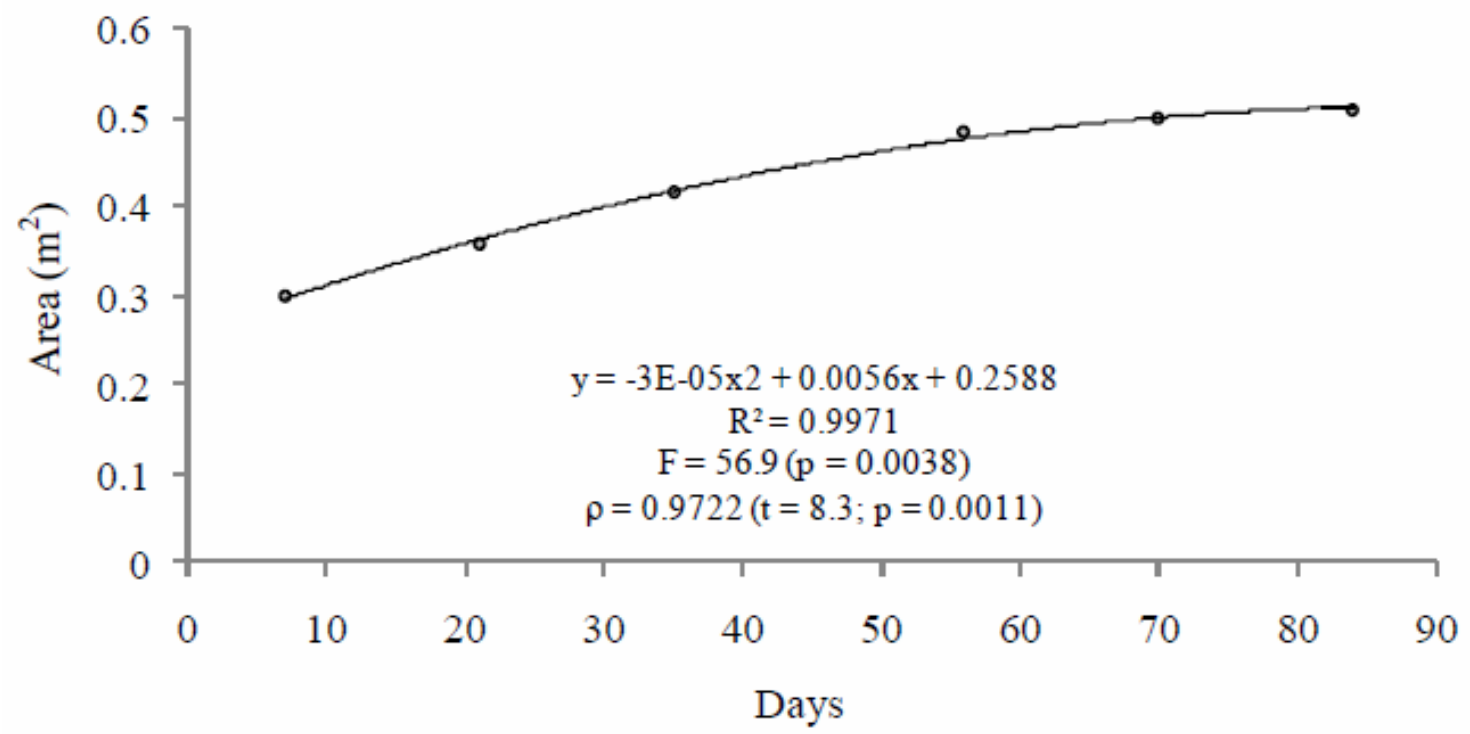

Figure 2. Regression of area expansion of Tradescantia zebrina per day on Campus II, UFPB, Areia-PB.

\section{Invasion velocity of $T$. zebrina}

The species exhibits a high invasion velocity, occupying territory very quickly, a common characteristic of invader species. The results showed that after seven days, T. zebrina reached its maximum rate of growth $\left(0.30 \pm 0.09 \mathrm{~m}^{2}\right)$, and started to slowing since then, characterizing a quadratic model $(\mathrm{F}=56.9 ; \mathrm{p}=0.0038$; $\left.\mathrm{r}^{2}=0.9971\right)$. At the end of evaluation (84 days) the species covered $0.51 \pm 0.15 \mathrm{~m}^{2}$ (Figure 1), which confirms the kind of aggressive behavior. According to the Pearson correlation coefficient $(\mathrm{r}=0.97, \mathrm{t}=8.3, \mathrm{p}=0.0011)$ there was $\mathrm{a}$ significant positive correlation, where, as the days passed there was an increase in the 
invaded area. The analysis showed significant proven through the values.

\section{Impacts of T. zebrina about the resilience of native vegetation}

The monthly accumulation of individuals in the parcels without the invader species (SE) and with them (CO) are present in the Figure 2. Here is possible to observe that in the SE treatment there was an increased accumulation along the time, while the $\mathrm{CO}$ treatment was almost stable, with few changes observed $(\mathrm{p}=0.021$ and $\mathrm{H}=5.327)$. In these plots there was no increase of individuals in the first reading, but there was an increase of approximately $15 \%$ in the second reading, remaining stable until the end of the evaluation. Unlike the plots (EC), the plots (SE) showed a slight accumulation of individuals at first reading, gradually increasing over the readings, coming to occupy approximately $70 \%$ of the assessed areas.

\section{Discussion}

\section{Populational Density, biomass and biometry of $T$. zebrina}

The elevated populational density of T. zebrina observed in the present study represents a strong threat to the native flora, because after them filling the soil surface, these individuals might interfere in the natural establishment of native plant species, fact already observed for its congener Tradescantia fluminensis Vell. (Pedrosa-Macedo et al., 2007). In several locals of the Campus it was possible perceive the presence of $T$. zebrina, in its majority in place under anthropogenic influence, below the dossel of trees used for landscape, as well as along edges and tracks. These environments, characterized by strong anthropism are fragile, with little richness and biodiversity, being subjected easily to the biological invasion (Davis et al., 2000).

In the Chilean scrublands, Castro et al. (2010) found an occupation around 98\% of the area by Anthriscus caucalis M. Bieb., resulting in decline of the local biodiversity throughout the time due to its acquired dominance, affecting directly the survival of four species. Invaders species, when find favorable environment conditions, increase their reproduction and growth rates, keeping themselves more time in the environment (Myers et al., 2000), resulting in higher densities, a common feature among invader species.

According to Parker et al. (1999) exist some factors that must be evaluated in an invasion situation to measure the caused environmental impact, highlighting among them, the abundance and area occupied by the species. Consequently, how bigger the occupied area and abundance, bigger it will be the impact due to the drift of the available resources lost by competition (Pimentel et al., 2001; Dias-Filho, 2006), resulting in the disappearing of native species (Tow and Lanzeby, 2001).

In Brazil T. zebrina apparently found the ideal conditions for its establishment, mainly in the South and Southeastern regions (Instituto Hórus de Desenvolvimento e Conservação Ambiental, 2005), being considered an invader in Curitiba municipality (Paraná State) (Biondi and Pedrosa-Macedo, 2008, Instituto Hórus de Desenvolvimento e Conservação Ambiental, 2005) and in the Pacific Islands (Pacific Island Ecosystems at Risk, 2006). These regions have mild temperatures with high moisture and precipitation as well as soil generally rich in organic matter, which are characteristics also found in the Areia Municipality. Such situation can be favorable to the rapid increase of density and occupation of this species. This hypothesis is easily proved by Pedrosa-Macedo et al. (2007), that in a study about the ecology of $T$. fluminensis in the Paraná State, observed that the presence of this species was stressed in the Mixed Ombrophylous Forests with high moisture and altitudes between 950-1000 m, being not registered the presence of populations in the drier areas like coast or lower altitude.

Some environments are more susceptible to invasion than others, being directly related to diversity and disturbance of the environment and the absence of competitors and parasites (Ziller, 2001), being the reduction in diversity generally result from a disturbance in the environment, so well preserved environments show no susceptibility to invasions (Rangel and Nascimento, 2011). 
Invasive alien species cause changes in the essential ecological (Ziller, 2001) because adapt easily to the new environment (Ziller and Galvão, 2002). It was observed that T. zebrina is resistant to trampling, tolerates frequent cuts and can even occupy areas of high slope. Studying invasive species Dracaena fragrans (L.) Ker-Gawl in the understory of the Tijuca Forest - Tijuca National Park (TNP), Ribeiro and Zau (2007) found the species density values of 0.92 ind. $/ \mathrm{m}^{2}$ areas down the side of a road and 0.19 ind $/ \mathrm{m}^{2}$ in areas above this slope, near the road, indicating that the species has spread colonization strategies and efficient to use the edges to invade the forest interior, which also happens to T. zebrina that seems to have begun its invasion process through the edges of the fragment present in Campus II. Yet according to the authors, the remaining forests, like that found in Areia, are divided into isolated fragments (forest fragment present in Campus II UFPB) that become subject to edge effects and biological invasions.

Even presenting high densities and becoming a threat to the environment, invasive species can be eradicated allowing the recruitment of native species, as explained by Medeiros and Ferreira (2011), that by using different treatments between soil management (which allowed the recruitment of native species seed bank soil); native grass species introduction and removal of invasive species Eragrostis plana Nees (grass annoni).

Biomass values were significantly different among the hundred adults and individuals selected sampling, where the latter had a high leaf biomass relative to leaf biomass of hundred individuals. This probably happened because individuals of the sample $\left(10 \mathrm{~m}^{2}\right)$ were taken randomly and without age criteria, involving those with perfilhamentos. The pattern of biomass accumulation in stoloniferous species, such as $T$. zebrina, is mainly characterized by the production of leaves, indicating the importance of stretching and rooting of stolons (Scheffer-Basso et al., 2002).

Martins et al. (2011) evaluated the influence of the grass biomass invasive Melinis minutiflora P. Beauv under the wealth of a community's original Cerrado and observed that it presented biomass equivalent to $62 \%$ of the experimental area, demonstrating its strong potential for modification under the herbaceous layer of the invaded areas. Likewise, biological invasions are responsible for changing the biomass of Australian savannas (Rossiter et al., 2003).

Already roots showed dry matter values well below the two variables, a common feature in stoloniferous herbaceous species. The production of roots is directly related to concentration of water and nutrients in the soil (Blair and Perfecto, 2001) and varies depending on the type of vegetation, since the morphological and strategic absorption depends on the species present in the area (Leuschner et al., 2004).

The fine roots of $T$. zebrina in natural conditions are attached to litterfall, which seems to serve as a support and source of nutrients. However, when studying legumes, Scheffer-Basso et al. (2002) found that one of them, Adesmia latifolia Spreng. Vog. had a system of fine roots coming from the nodes of stolons and lower biomass compared to other legumes studied, as well as T. zebrina, which indicates, according to them, that their survival depends more on conditions of humidity.

\section{Invasion velocity of $T$. zebrina}

The rapid speed of invasion found can be explained by how invasive species outweigh the environmental barriers, invading and dominating the new environments (Richardson et al., 2000). The search for dominance of territory reflects the impacts that may cause the species, since, to overcome the environmental barriers, they get the domain of the territory through the high reproductive capacity, dispersion and end up limiting competition and the development of native species may be extinct (Pivello, 2008).

It is important to investigate the coverage ratio above which the presence of an invasive species affect native species richness of the invaded area. Australian areas with coverage of invasive species Lantana camara L. greater than $75 \%$ (Gooden et al., 2009), and coverage of Asparagus asparagoides (L.) Druce from $40.3 \%$ and $61.7 \%$ (Turner et al., 2008) showed a rapid decline of native species. In 
Brazil, in a first survey of the presence of Archontophoenix cunninghamiana $\mathrm{H}$. Wendl. \& Drude in Reserve of the Cidade Universitária "Armando de Salles Oliveira" (Cuaso), in São Paulo, Dislich et al. (2002) found one hundred seventy-four adults and two and a half years later, only three of these had died and eighty-nine new individuals had emerged and occupied new areas. This behavior represents an adaptive advantage against the other native species that helps in their rapid occupation and domination.

\section{Impacts of $T$. zebrina about the resilience of native vegetation}

In plots (EC) adding individuals only on the first reading followed by stabilization may have occurred because of the slight "disturbance" exercised after the count of individuals in the first reading showing the speed that these individuals have to respond to stimuli from the environment.

Similar results related to stabilize the growth of $T$. zebrina in plots already occupied was found by a study by Cheung et al. (2009) that observed where the number of individuals grown herbaceous in early abandonment of the area but was decreased with time for both herbaceous and for the native herbaceous exotic. However, for the latter, in the areas of recent abandonment, the number of individuals was much higher when compared to areas with longer abandonment that showed a marked decrease. Possibly this is a result of the stabilization strategy of expansion and domination of those species that cannot be spending its reserves growing, instead, seek to expand into new areas, remaining stable in areas where they are already established.

Since the plots (SE) showed different behavior of the plots (EC) rapidly occupying the areas assessed. This result demonstrates the ability to respond to perturbations of this kind, so that the ten months almost the entire area was occupied explaining the interference potential of this species in natural regeneration of areas in which occupies the same.

Invasive alien species have characteristics that favor its rapid growth as vegetative propagation (Miles et al., 1996) which results in a greater competitive ability (Moraes and Pereira, 2003) and consequent accumulation of biomass, which was observed in the plots (SE) that may have been influenced by the embedded seedlings in the soil even after removal of individuals.

In a survey of invasive plant species on the Campus of PUC-SP, Siqueira (2006) revealed the presence of a population of T. zebrina and highlighted its high ground cover and easy to multiply by cuttings, preventing the development of seedlings and seed germination, similar to other species of the family as Commelinaceae T. fluminensis that has no literary records of fruiting and seed production, spreading across its nodules (Pedrosa-Macedo et al., 2007).

According to Cubiña and Aide (2001), the velocity and efficiency of natural regeneration depends of several factors, among them, the availability of propagules in the soil and close fragments. Both can explain the fast expansion of T. zebrina in the Campus II UFPB, because the presence of exotic species in urban areas can work as an important irradiator center for biological invasions (DehnenSchmutz et al., 2007). It is evident that in the Campus II UFPB, the availability of specimens originating from residences and Departments where they are cultivated as ornamental plants.

Heiden et al. (2007) evidenced that in Rio Grande do Sul State (Brazil) several species introduced as ornamentals became surrogates of native flora, without researchs evaluating the damages. Among them detached the species "maria-sem-vergonha" (Impatiens walleriana Hook.) that can to shade outer and inner forest species what is similar with the T. zebrina in the Campus II UFPB.

In the Cerrado das Emas-SP, exotic grasses like Melinis minutiflora P. Beauv. and Brachiaria decumbens (Stapf.) Webster, showed a pattern of spatial distribution started through the forest edges, the edges of roads or tracks and began to cover the entire ground by which established (Pivello et al., 1999a, b). The strong presence of T. zebrina in the Campus II can is linked to the fact that the environment is fragmented and 
anthropogenic, not being found reports of abundance of this species in conservation areas. In a study conducted in abandoned pastures in Paraná, Cheung et al. (2009) observed that areas recently abandoned (eight and fourteen months) presented several species of exotic grasses and the richness and density of woody species correlated negatively with the presence of exotic herbaceous species. This study demonstrated that there is significant change floristic and structural vegetation in the first four years of abandonment of pastures, suggesting that the vegetation promoted by herbs, especially the exotic, are negatively impacting the natural regeneration of the Rain Forest.

Leão et al. (2011) identified the species T. zebrina as invasive in the state of Rio Grande do Norte at medium risk of invasion, responsible for hindering the natural regeneration of native species invading understory of forest in regeneration stage, altering the conditions for the establishment of native seedlings. In the same work was affirmed the presence of invasive species in Hawaii, Galapagos Island, Fiji, Cook Islands and France, however, the number of occurrences recorded is still small, not reflecting the reality of alien invasive species in the Brazilian northeastern. Thus more research is needed to discover and describe biological invasions in this region.

\section{Conclusions}

The results for density, invasion velocity and resilience capability evidenced the biological invasion in Campus II for T. zebrina, being inevitable the increase of the impact on the studied area.

The collected data are only preliminary information about the species, however, has justified the adoption of measures of population control. The low number of records is an indication that little is known about the invasive potential of this species, there is a need for more research to better describe the behavior of this species.

The information obtained in this study may help in an attempt to prevent further damage in the future, since without effective control, in a few years this species will occupy disorderly available space, preventing the development of native species and impoverishing local biodiversity.

\section{References}

Ayres, M.; Ayres, M. J.; Ayres, D. L.; Santos, S. A. Bioestat 5.0: aplicações estatísticas nas áreas das Ciências Biomédicas. Belém: Mamirauá/CNPq, 2007.

Barbosa, M. R. V.; Agra, M. F.; Andrade, L. A.; Cunha, J. P.; Sampaio, E. V. S. B. Diversidade florística da Mata do Pau-Ferro, Areia, Paraíba. In: Pôrto, K. C., Cabral, J. J. P.; Tabarelli, M. (Ed.). Brejos de altitude em Pernambuco e Paraíba: história natural, ecologia e conservação Brasília: Ministério do Meio Ambiente, 2004. p. 111-122. (Série Biodiversidade, v. 9).

Biondi, D; Pedrosa-Macedo, J. H. Plantas invasoras encontradas na área urbana de Curitiba (PR). Floresta, v. 38, p. 129-144, 2008.

Blair, B. C.; Perfecto, I. Nutrient content and substrate effect on fine root density and size distribution in a Nicaraguan Rain Forest. Biotropica, v. 33, p. 697-701, 2001.

Casimiro, A. C. R.; Ashikaga, F. Y.; Kurchevski, G.; Almeida, F. S.; Orsi, M. L. Os impactos das introduções de espécies exóticas em sistemas aquáticos continentais. Boletim da Sociedade Brasileira de Limnologia, v. 38, 12 p., 2010.

Castro, S. A.; Badano, E.; Guzman, D.; Cavieres, L. Biological invasion of a refuge habitat: Anthriscus caucalis (Apiaceae) decreases diversity, evenness, and survival of native herbs in the Chilean matorral. Biol. Invasions, v. 12, p. 1295-1303, 2010.

Cheung, K. C.; Marques, M. C. M.; Liebsch, D. Relação entre a presença de vegetação herbácea e a regeneração natural de espécies lenhosas em pastagens abandonadas na Floresta Ombrófila Densa do Sul do Brasil. Acta bot. bras., v. 3, p. 1048-1056, 2009.

Cubinã, A.; Aide, T. M. The effects of distance from forest edge on seed rain and soil seed bank in a tropical pasture. Biotropica, v. 33, p. 260267, 2001.

Davis, M.A.; Grime, J.P.; Thompson, K. Fluctuating resources in plant communities: a general theory of invasibility. Journal of Ecology, v. 88, p. 528-534, 2000.

Dehnen-Schmutz, K.; Touza, J.; Perrings, C.; Williamson, M. A century of the ornamental plant trade and its impact on invasion success. Diversity Distrib., v. 13, n. 5, p. 527-534, 2007. 
Dias-Filho, M. B. Competição e sucessão vegetal em pastagens. Belém: Embrapa Amazônia Oriental, 2006.

Dislich, R.; Kisser, N.; Pivello, V. A invasão de um fragmento florestal em São Paulo (SP) pela palmeira australiana Archontophoenix cunninghamiana H. Wendl. \& Drude. Rev. bras. Bot., v. 25, p. 55-64, 2002.

Gooden, B., French, V.; Turner, P.J. Invasion and management of wood plant, Lantana camara L., alters vegetation diversity within wet sclerophyll forest in southeastern Australia. Forest Ecology and Management, v. 257, p. 960-967, 2009.

Heiden, G.; Stumpf, E. T.; Barbieri, R. L.; Grolli, P. R. Uso de plantas subarbustivas e herbáceas nativas do Rio Grande do Sul como alternativas a ornamentais exóticas. Rev. Bras. Agroecologia, v. 2, p. 850-853, 2007.

Instituto Hórus de Desenvolvimento e Conservação Ambiental. Tradescantia zebrina, 2005. Available from: <http://www. institutohorus.org.br/download/fichas/

Tradescantia_zebrina.htm $>$. Accessed in: May $11,2010$.

Jorge, L. A. C.; Silva, D. J. C. B. SisCob: software para a análise cobertura vegetal. Embrapa, Instrumentação Agropecuária, 2003.

Leão, T. C. C.; Almeida, W. R.; Dechoum, M.; Ziller, S. R. Espécies exóticas invasoras no Nordeste do Brasil: contextualização, manejo e políticas públicas. Recife: Centro de Pesquisas Ambientais do Nordeste (CEPAN) e Instituto Hórus de Desenvolvimento e Conservação Ambiental, 2011.

Lehmann, E. L. Testing statistical hypotheses. 2nd ed. New York: Springer-Verlag, 1997.

Leuschner, C. L.; Hertel, D.; Schmid, I.; Koch, O.; Muhs, A.; Hölscher, D. Stand fine root biomass and fine root morphology in oldgrowth beech forests as a function of precipitation and soil fertility. Plant and Soil, v. 258, p. 43-56, 2004.

Lockwood, J. A.; Purcell, M. F.; Howarth, F. G. (Ed.). Balancing nature: assessing the impact of importing non-native biological control agents (an international perspective). Lanham: Thomas Say Publications in Entomology, 2001.

Lorenzi, H.; Souza, H. M. Plantas ornamentais no Brasil: arbustivas, herbáceas e trepadeiras. São Paulo: Plantarum, 2001.

Ludsin, S. A.; Wolfe, A. D. Biological invasion theory: Darwin's contributions from The Origin of Species. Bioscience, v. 51, p. 780-789, 2001.

Mack, R. N.; Simberloff, D.; Lonsdale, W. M.; Evans, H.; Clout, M.; Bazzaz, F. Biotic invasions: Causes, epidemiology, global consequences and control. Issues in Ecology, v. 5, p. 1-25, 2000.

Martins, C. R.; Hay, J. D. V.; Walter, B. M. T.; Proença, C. E. B.; Vivaldi, L. J. Impacto da invasão e do manejo do capim-gordura (Melinis minutiflora) sobre a riqueza e biomassa da flora nativa do Cerrado sentido restrito. Rev. bras. Bot., v. 34, p. 73-90, 2011.

Mayo, S. J.; Fevereiro, V. P. B. Mata do PauFerro: a pilot study of the brejo forest. Kew: Royal Botanic Gardens, 1982.

Medeiros, R. B.; Ferreira, N. R. Controle de invasão biológica por capim-anonni em margem viária mediante a introdução de gramíneas. R. Bras. Zootec., v. 40, p. 260-269, 2011.

Meffe, G. K.; Carroll, C. R. Principles of conservation biology. Sunderland: Sinauer Associates, 1997.

Miles, J. W.; Maass, B. L.; Valle, C.B.; Kumble, V. Brachiaria: biology, agronomy, and improvement. Campo Grande: CIAT/ Emprapa-CNPGC, 1996.

Moraes, L. F. D.; Pereira, T. S. Restauração ecológica em unidades de conservação. In: Kageyama, P. Y. (Org.). Restauração ecológica de ecossistemas naturais. Botucatu: FEPAF, 2003. p. 297-305.

Müeller-Dombois, D.; Ellenberg, H. Aims and methods of vegetation ecology. New York: Wiley, 1974.

Myers, J. H.; Simberloff, D.; Kuris, A. M.; Carey, J. R. Erradication revisited: dealing with exotic species. Trends in Ecology \& Evolution, v. 5, p. 316-320, 2000.

Pacific Island Ecosystems at Risk. Available from: $\quad<$ http://www.hear.org/pier/threats.htm>. Accessed in: Apr. 8, 2012.

Parker, I. M.; Simberloff, D.; Lonsdale, W. M.; Goodell, K.; Wonham, M.; Kareiva, P. M.; Williamson, M. H.; Vonholle, B.; Moyle, P. B.; Byres, J. E.; Goldwasser, L. Impact: toward a framework for understanging the ecological effects of invaders. Biol. Invasions, v. 1, p -19, 1999.

Pedrosa-Macedo, J. H.; Weigert, J. K.; Scapini, L. A.; Niederhartmann, D.; Bebiano, D. R.; Fowler, S.; Waipara, N. Estudos bioecológicos sobre Tradescantia fluminensis (Commelinaceae) e seus inimigos naturais associados no Paraná. Floresta, v. 37, p. 31-41, 2007.

Pimentel, D.; Mcnair, S.; Janecka, J.; Wightman, J.; Simmonds, C.; O'Connel, C.; Wong, E.; Russel, L.; Zern, J.; Aquino, T.; Tsomondo, T. Economic and environmental threats of alien plant, and microbe invasions. Agriculture, Ecosystems and Environment, v 84, p. 1-20, 2001. 
Pivello, V. Invasões biológicas no Cerrado brasileiro: efeitos da introdução de espécies exóticas sobre a biodiversidade. ECOLOGIA.INFO, 33, 2008. Available from: $<$ http://www.ecologia.info/cerrado.htm $>$. Accessed in: Apr. 26, 2010.

Pivello, V.R.; Shida, C.N.; Meirelles, S. T. Alien grasses in Brazilian savannas: a threat to biodiversity. Biodiversity and Conservation, v. 8, p. 1281-1294, 1999a.

Pivello V. R.; Carvalho, V. M. C.; Lopes, P. F.; Peccinini, A. A.; Rosso, S. Abundance and distribution of native and invasive alien grasses in a "cerrado" (Brazilian savanna) biological reserve. Biotropica, v. 31, p. 71-82, 1999b.

Rangel, E. S.; Nascimento, M. T. Ocorrência de Calotropis procera (Ait.) R. Br. (Apocynaceae) como espécie invasora de restinga. Acta bot. bras., v. 25, p. 657-663, 2011.

Ribeiro, M. O.; Zaú, A. S. Levantamento populacional e manejo da exótica invasora Dracaena fragrans (L.) Ker-Gawl (Angiospermae - Liliaceae), em um trecho de Floresta Atlântica sob efeitos de borda no Parque Nacional da Tijuca, Rio de Janeiro, RJ. Revista Brasileira de Biociências, v. 5, p. 2123, 2007.

Richardson, D. M.; Pysek, P.; Rejmánek, M.; Barbour, M. G.; Panetta, F. D.; West, C. J. Naturalization and invasion of alien plants: concepts and definitions. Diversity Distrib., v. 6, p. 93-107, 2000.

Rodgers, J. L.; Nicewander, W. A. Thirteen ways to look at the correlation coefficient. The American Statistician, v. 42, p 59-66, 1998.

Rodolfo, A. M; Temponi, L. G.; Cândido, J. F. Levantamento de plantas exóticas na trilha do Poço Preto, Parque Nacional do Iguaçu, Paraná, Brasil. R. bras. Bioci., v. 6, p. 22-24, 2008.

Rossiter, N. A.; Setterfield, S. A.; Douglas, M. M.; Hutley, L. B. Testing the grass-fire cycle: alien grass invasion in the tropical savannas of northern Australia. Diversity Distrib., v. 9, p. 169-176, 2003.

Santos, A. C. J.; Melo, J. I. M. Flora vascular de uma área da Caatinga no Estado da Paraíba -
Nordeste do Brasil. Revista Caatinga, v. 23, p. 32-40, 2010.

Scheffer-Basso, S. M.; Jacques, A. V. A.; Agnol, M. D. Alocação da biomassa e correlações morfofisiológicas em leguminosas forrageiras com hábitos de crescimento contrastantes. Sci. agric., v. 59, p. 629-634, 2002.

Silva, M. C.; Queiroz, J. E. R.; Araújo, K. D.; Pazera Jr., E. Condições ambientais da Reserva Ecológica Estadual da Mata Pau Ferro, AreiaPB. Revista Geografia, v. 15, p. 51-63, 2006.

Silva, J. M. C.; Tabarelli, M.; Fonseca, M. T. O processo de seleção de áreas e ações prioritárias para a conservação da Caatinga. In: Silva, J. M. C.; Tabarelli, M.; Fonseca, M. T.; Lins, L. V. (Org.). Biodiversidade da Caatinga: áreas e ações prioritárias para a conservação. Brasília: Ministério do Meio Ambiente, 2003.

Siqueira, J. C. S. Bioinvasão vegetal: dispersão e propagação de espécies nativas e invasoras exóticas no Campus da Pontifícia Universidade Católica do Rio de Janeiro (PUC-Rio). Pesquisa Botânica, v. 57, p. 319-330, 2006.

Tow, P. G.; Lazenby, A. Competition and succession in pastures: some concepts and questions. In: Tow, P. G.; Lazenby, A. (Ed.). Competition and succession in pastures. Wallingford: CABI Publishing, 2001. p. 1-13.

Turner, P. J., Scott, J. K.; Spafford, H. The ecological barriers to the recovery of bridal creeper (Asparagus asparagoides (L.) Druce) infested sites: impacts on vegetation and the potential increase in other exotic species. Austral Ecology, v. 33, p. 713-722, 2008.

Ziller, S. R. Os processos de degradação ambiental originados por plantas exóticas invasoras. 2001. Available from: <http://www. institutohorus.org.br/download/artigos/Ciencia \%20Hoje.pdf>. Accessed in: Apr. 25, 2010.

Ziller, S. R.; Galvão, F. A degradação da estepe gramíneo-lenhosa no Paraná por contaminação biológica de Pinus elliottii e Pinus taeda. Floresta, v. 32, p. 42-47, 2002. 